$\begin{array}{ll}\text { Abstracta Iranica } & \begin{array}{l}\text { Abstracta Iranica } \\ \text { Revue bibliographique pour le domaine irano-aryen }\end{array} \\ & \text { Volume } \mathbf{2 4} \text { | } \mathbf{2 0 0 3} \\ \text { Comptes rendus des publications de } \mathbf{2 0 0 1}\end{array}$

\title{
Les doctrines de la science de l'Antiquité à l'âge classique. Louvain, Peeters, 1999.
}

\section{Živa Vesel}

\section{(2) OpenEdition}

1 Journals

Édition électronique

URL : http://journals.openedition.org/abstractairanica/34592

DOI : 10.4000/abstractairanica.34592

ISSN : 1961-960X

Éditeur :

CNRS (UMR 7528 Mondes iraniens et indiens), Éditions de l'IFRI

\section{Édition imprimée}

Date de publication : 15 mai 2003

ISSN : 0240-8910

\section{Référence électronique}

Živa Vesel, «Les doctrines de la science de l'Antiquité à l'âge classique. Louvain, Peeters, 1999. », Abstracta Iranica [En ligne], Volume 24 | 2003, document 194, mis en ligne le 05 janvier 2010, consulté le 25 septembre 2020. URL : http://journals.openedition.org/abstractairanica/34592 ; DOI : https:// doi.org/10.4000/abstractairanica.34592

Ce document a été généré automatiquement le 25 septembre 2020.

Tous droits réservés 


\section{Les doctrines de la science de l'Antiquité à l'âge classique. Louvain, Peeters, 1999.}

\section{Živa Vesel}

1 Recueils d'articles consacrés à l'analyse de la formation des doctrines scientifiques, notamment sous l'angle de la philosophie. Les articles suivants concernent, ne serait-ce qu'en partie, l'histoire des sciences du monde iranien: R. Rashed, "Combinatoire et métaphysique : Ibn Sīnā, al-Tūsī et al-Halabī”; R. Morelon, "Astronomie 'physique' et astronomie 'mathématique' dans l'astronomie précopernicienne”; G. Saliba, "Astronomy and Astrology in Medieval Arabic Thought" et J. Jolivet, "Classification des sciences arabes et médiévales". Ouvrage fondamental pour toute étude sur la science islamique.

\section{INDEX}

Thèmes : 10. Histoire des Sciences et des Techniques

\section{AUTEURS}

ŽIVA VESEL

CNRS - Paris 